metal being found in certain islands north of Spain was sufficient to secure for them the distinctive title of Insula Cassitcrides, or Tin Islands.

G. F. RODWELI,

\section{The Greenwich Date}

UNDER this heading, in your number for Nov. 28, a letter signed "James Pearson" ends thus:- "The query then is-in what part of the globe and in what meridian does October 20 end and October $2 \mathrm{I}$ begin?" As well ask where a circle ends and where it begins. See an article at the end of Bayle's Dictionary, entitled, in the second Rotterdam edition, 1702 " Dissertation sur le jour," vol. iii. p. 3 I 8 ; in the London edition, I74I, "Dissertation concerning the Space of Time called Day," vol, $x$. p. 365. The difficulty, as Bayle shows, is in the nature of things. Let an equatorial railroad go round the world in twentyfour hours, with a station at every $45^{\text {th }}$ meridian. At noon of October 20, Mr. West takes "a return ticket" westward; Mr. East takes one eastward. Both reckon by solar time. At every station Mr. West finds it noon, and on his return home reckons noon October 20 ; but the station-master reckons noon October 2I. Mr. East at $45^{\circ}$ sees the sun set at $60^{\prime}$ clock. At $90^{\circ}$ he finds midnight ; at $135^{\circ}$ the sun rises at $60^{\prime}$ clock on October 21 ; at $180^{\circ}$ it is noon. Here the two passengers pass each other, $\mathrm{Mr}$. West reckoning it to be noon of October 20, Mr. East noon of October 21. At $135^{\circ}$ W., Mr. East sees the sun set at $90^{\circ}$

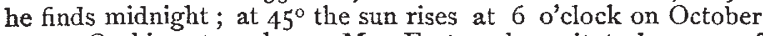
22. On his return home Mr. East reckons it to be noon of October 22. Here then are three different reckonings, and practically the keeping of Sunday, Christmas Day, \&c., on different days in different countries exists at this instant and must exist for ever. Practically also those who sail eastward round the world get one more dinner than those who stay at home. Those who sail westward round the world get one dinner less than those who stay at home, and two dinners less than those who sail eastward, when both voyages are completed.

Brookwood Park, Alresford, Nov. 30 George Greenwood

Mr. Pearson's query, in Niture of November 28 , docs not admit of any exact or scientific answer, for there is no natural line of demarcation or change, and the settlement is entirely a matter of usage or convenience. It is not very many years since the dates at Manilla and Macao were different; and till the cession of the Alaska Territory to the Americans, the date there was different from that in the British Territory adjoining. The rule now generally held is, that places in E. long. date as if they were arrived at by the Cape of Good Hope, and places in W. long as if they were reached via Cape Horn-a rule that the width of the Pacific renders practically convenient. Afloat, the rule is for a ship making a passage to change her date on crossing the meridian of $180^{\circ}$, or as soon after as the captain may find convenient; repeating or omitting a day, according to the direction in which she is going; but a ship merely cruising across the meridian, with the intention of returning, does not generally change her date, so that ships having different dates may and do occasionally meet - a very marked instance of which occurred during the Russian war, when our squadron from the Pacific joined the China squadron on the coast of Kamschatka.

And thus, according to established usage, October $2 I$ at Adelaide, and October 21 at the hypothetical place in $9 \mathrm{~h} .35 \mathrm{~m}$. W. long., are different days; in the two places October 21 has a different meaning.

Royal Naval College, Dec. I

J. K. LAUGHTON

THE Rev. J. Pearson is correct in the method of finding the corresponding Greenwich date, although its numerical performance is incorrectly performed in his letter.

It is absolutely necessary for practical purposes to draw the line somewhere, and it is drawn in England an her colonies as well as in America and Russia, at the meridian $180^{\circ} \mathrm{E}$. of Greenwich. The limit, therefore, of the longitude to be added to or subtracted from the Greenwich date will not exceed twelve hours.

It is usual for sailors, when crossing this meridian, to skip a day, or to reckon the same day over agzin, according as the meridian has been reached from the eastward or westward.
An instance of this apparent anomaly is furnished in the Appendix to the "Nautical Almanac" for 1874. The time of the phenomenon of the transit of Venus over the sun's disc takes place generally about December $8, \mathrm{I} 6 \mathrm{~h}$. Greenwich astronomical time. Its recorded local astronomical time for the middle of the transit at Auckland, New Zealand (long. $174^{\circ} 42^{\prime}$ E.), is Decem. ber $9,3^{\text {h. }}$ 40m. ; but for Woahoo (long. $15^{\circ} \mathrm{W}$.) the time of the first contact of Venus with the sun's limb takes place at December 8, 3h. $4.7 \mathrm{~m}$.

Blackheath Road, Greenwich, Dec. 2

\section{Comets' Tails}

CAN any of your readers refer me to a work by a recognised authority in astronomy in which I can find the method by which the direction of a comet's tail, as regards that of the heliocentric radius-vector of the head, has been calculated from observation? Or, more briefly, have we any proof whatever that there is other than an occasional chance coincidence of these two directions?

G. H.

\section{REMARKS ON THE ZOOLOGY OF THE}

$$
\text { FAROE ISLANDS }
$$

$A S$ I have already announced in this paper, I started $A$ with the Danish expedition in September from Copenhagen, and arrived after a very fortunate voyage of four days in Torshavn, the little capital of Faroe in the isle of Strömö. There I intended to remain while our steamer, with the geologists and engineers, went to the southern island (Suderö), where the miocenc coal deposits are to be seen some hundred feet above the level of the sea in the basaltic rocks near the village of Qualbö. As to their researches about the extension of the coal-fields in Suderö, directed by Prof. Johnstrup, and as to the possibility of taking the coals over to Copenhagen at a reasonable price, I cannot say anything now, as the report must first be made to the Minister of the Interior, who will perhaps afterwards publish the results. Some words, however, about my own zoological researches in Torshavn will, I think, have some interest for the readers of NATURE.

I remarked in my preceding paper that no wild mammals were known to eccur in the islands, except some species of the genus Mus. This is, as I now know, not quite correct; for some thirty or forty years ago the northern hare (Lchus alpinns) was introduced into the islands, and it seems to have met with very favourable conditions of life, as it is now spread in considerable numbers over Strömö, and has also been brought to Oesterö. The hare finds ample food in the grasses covering the ground; the large rocks spread everywhere protect him, and no mammals or birds of prey endanger his life, with the exception of Corvus corax, or the little Fialco aesalon, which sometimes might take the youngcr ones. The occurrence of the Falco islandicus is too rare to do any serious damage to the hares. Besides these, they have also endeavoured to introduce the "ripers" (Tetrao lagopus) so common in Iceland and Norway, but those set free have perished without breeding. These birds require food and protection from trees, which, as it is known, do not occur in these islands.

The rats found in the northern islands of Faroe (although they have not yet come to all the islands) belong to the species Mus decumanus, which here, as nearly everywhere in Europe, has nearly destroyed the smaller black rat (Mus rattus), still, however, to be found in some houses of Suderö. In the "fields" still another species of rat is said to occur, not heretofore seen by naturalists. Mr. Randrop of Torshavn, who has taken great trouble in order to secure a specimen of the animal, the footsteps of which he has seen, thinks it is the Lemmus norvegicus, but he could never get it. Among the large aquatie mammals the "Grindehval "(Delphinus globiceps) is known to be of great importance here, as nearly every year large flocks of it are taken, which they drive to the 
shore by boats, and the flesh of which is divided after old northern laws still in use in this country. Some hundreds of this whale had just been killed in Westmannshavn (west side of Strömö) some days before we arrived, and I still could examine pieces of the animals brought to Torshavn. I immediately looked after external parasites, but would not have got them if Sysselmand Müller, the wellknown magistrate and naturalist of Torshavn, had not had the kindness to give me some specimens. These are two species of Cirripedia, one of them being an Otion, which often attaches itself to the teeth of the dolphin, where it easily finds food; as the surface water, coming in, is full of little creatures (infusoria, crustacea, \&c.), which the Otion catches by aid of its arms. Another very interesting external parasite of the dolphin is the Xenobalanus glo. bicipitis Steenstr., which Sysselmand Müiler has discovered in large numbers on the fins of the whale. An allied species, also described by Steenstrup, is found on the fins of Uranodon rostratus, a whale met with in small flocks of four and five, especially near the southern island, where one of them was killed during the stay of the expedition. In 'Torshavn I also sought to get the intestines of the grindehval; but these, of course, had already been $t$ urown into the sea, with the exception of the stomach, in which I have found the rests of Cephalopods, the usual food of this whale, and the common Ascaris.

At the time when we arrived in Faroe the celebrated "Fuglebjergs" (bird-rocks) were unfortunately already descrted by their inhabilants, so that I have seen nothing of their extraordinary life. Of one of them Sysselmand Miller has taken up excellent photograplic views (Troll. hovedet, near Sandö), which give a very gosd idea of them, and deserved to be published in an ornithological work. We see in it clearly the different stages which the birds occupy in the rocks, the highest of them being the sea-parrot (Mormon fratercula), then a Larus, and undermost Uria. Only the little Tizalassidroma pelagica was said to be still breeding (Sepicmber), and 1 therefore resolved to see tine rests. In the rocks of the northeastern side of Naalsö these little birds breed in a depth of one or two feet, their nest being simply a hole in the earth. One of the natives lifted the stones for me, then bent his ears to the holes, and, when he heard the birds piping, broke them up. In this manner we took an egg containing an embryo, with the old bird, which did not even endeavour to run or hy away, and three younger ones in different stages of growth. The Thalassidroma have only one egg, but they seem to breed twice or thrice a year. In the neighbourhood of this place, they told me, the nests of Procellaria glacialis were also to be found. Besides these, the birds usually met with were Authus campestris, Saxicola cenanthe, Motacilla alba, Troglodytes parvulus, Trunga variabilis and islandica, Numenius phaopus, and Hamatopus ostralegus, Carbo, sterna, Larus, \&c. We also got some living specimens of Sula alba, only occurring in the island of Myggenaes, and of Lestris cataractes, now not very common in Faroe, for the Zoological Garden in Copenhagen. Occasionally they have also taken the Pastor roseus and once Syr rhafites paradoxus. The former bird is known to appear sometimes in Norway and Heligoland (nearly every summer) - a very remarkable fact, as these birds, whicl are known to breed in Southern Russia and Asia Minor, have so very stldom becn met with in Denmark or in the interior of Germany.

Fishes are caught abundantly on the shores of Faroe; so that, for example, the klippfish trade is very considerable. The Gadus are opened, spread out and dried on the rocks (klipps), and are exported to Spain and France, their swim-bladders being used for the fabrication of gelatine, ard their ovaries being prepared for the use of the anchovy fishers in the Mediterranean. Of remarkable tishes only the Lampris guttutus Brinu was taken during my stay in Faroe, inhabiting the great depths of the Atlantic, and coming only by accident to the shores of these islands. This was the third specimen taken there, an enormous creature, weighing $76 \mathrm{D}$ anish pounds, having a length of 99 centimetres, and a breadth of 52 . The colour was a magnificent silver blue with red spots; it had been taken by the fishers in the King's Harbour (Kongshavn), and was admired, when brought to Torshavn, by large crowds of people who had never seen it. Before dissecting it, Sysselmand Müller took a photograph,

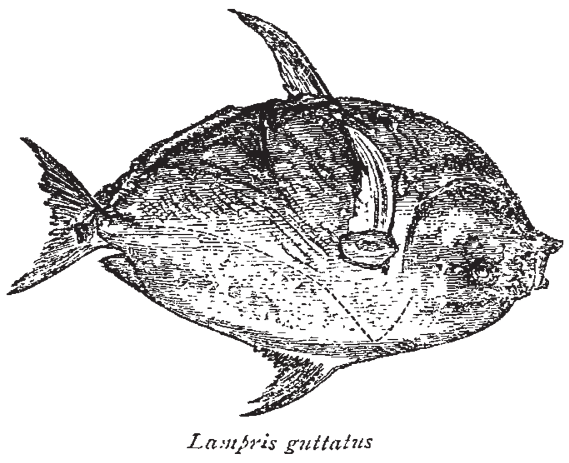

which has been reproduced in the ac sompanying woodcut. We then separated the principal muscles from the bones (the flesh looked like salmon's, bat its taste was not quite so good), in order to get the skeleton, and I dissected the intestines. In the stomach I found the same remains of Cephalopods, which also Kröyar mentions (tn "Danmarks Fiske") in the specimens he examined. Of the internal parasites I may here only mention an agramic Ascaris in the outer walls of the stomach, and a cestoid in the intestinum tonue. External parasites were eagerly sought for, but not found.

Very interesting to me were the lakes in the interior of the islands, as I hoped to get there something like those animals ("relicts") found in the lakes of Sweden and North America. I accordingly dredged in one of them, but did not find anything of importance. I also examined the three species of Salmonidæ of these lakes, one of them being the Salmo salvelinus, known to to be found in the lakes of Upper Bavaria and of Scotland. More about these inhabitants of the Faroe lakes may shortly be seen from a paper which $I$ am to publish in v. Siebold and Köliker's Zeitschrift; and the same periodical will also contain the results of my investigations on the Annelids from the shores of Faroe, which formed the principal object of my researches. I may here only remark that, on the whole the invertebrate fauna of the shores of Faroe, as well as of Iceland, is very poor compared with that of Greenland, Norway, or Denmark; so that the place is not to be recommended to those who wish to get in an easy manner favourable objects for anatomical or embryological observations. When I was there the currents were sometimes so strong that, even with the heavy oyster-dredges of Jutland, we did not reach farther down than 15 or 20 fathoms. And as to the surface-fauna, it was, with the exception of some few days, quite impossible to do anything, as the sea was too much agitated. In midsummer, of course, all those obstacles will vanish. Nevertheless, I cotild every day get fresh materials, as when the sea was rough I was sitting on the rocks of the shore, and selecting the animals from the sand and sea-weeds brought up in the harbour of Torshavn by my fisher, Zacharias Hansen, a very brave man, whom I recommend to every naturalist coming to Faroe in the future. With respect to comfort, my stay in the island was very agreeable, thanks to the care which Mr. and Mrs. Hansen were always good enough to take of me.

RUD, V. WILLFMOES-SUHM 